\title{
A comunicação dos afetos no tango: função, improvisação, sexualidade e ambivalências na linguagem da dança
}

\author{
Paulo Roberto Masella Lopes \\ Doutor; Universidade de São Paulo \\ paulomasella@gmail.com
}

Resumo

Apesar de seu complexo sistema de codificação, a linguagem do tango como dança somente pode ser compreendida por intermédio das constantes improvisações que seus pares executam, exigindo uma fina sintonia nas suas intenções de movimento. No entanto, a linguagem do tango excede essas circunstâncias, constituindo-se numa comunicação dos afetos que se revela em uma experiência única que não pode ser reproduzida. Ainda que se queira fazer do tango uma representação da sensualidade entre o homem e a mulher, propõe-se aqui uma crítica dessa identidade de gêneros, mostrando que sua expressão estética transcende essa determinação social, angariando um conjunto de representações ambivalentes que não se sujeitam a interpretações únicas. Neste artigo, embora se conceba o tango como um espaço semiótico próprio, busca-se também compreender sua linguagem corporal como um complexo sistema cultural aberto a constantes ressignificações através de algumas associações com outras formas de linguagem e representações sociais.

\section{Palavras-chave}

Espaço semiótico. Linguagem corporal. Identidade de gênero. Ambivalência. Sistema cultural. Tango.

\section{Introdução: para além das regras de linguagem}

Como sucede com a música, que combina harmonicamente as notas dos instrumentos em uma sequência melódica para formar um sentido musical, a dança realiza um arranjo de códigos corporais que desempenham funções no interior de sua estrutura a partir de um 
elemento comum a esses dois sistemas: o ritmo. Compartilhando de uma gênese comum, a música e a dança do tango sofreram basicamente a mesma influência rítmica sobre a qual não há registros suficientes senão para fazer algumas conjecturas a respeito. De fato, pouco se sabe sobre as origens do tango dançado na passagem do século XIX ao XX. Há especulações diversas, mas nenhuma documentação dos detalhes coreográficos e apenas algumas crônicas de jornais e relatos literários que enfatizam mais o mal-estar social que a suposta coreografia ousada gerava do que uma descrição dos seus códigos gestuais (FERRARI, 2011; PUJOL, 2011). A esse respeito, atesta o jornal La Nación em dezesseis de dezembro de 1896:

O que se dança? Uma habanera, uma milonga, uma polca, uma mazurca. Como se dança? Trata-se de um quadro curiosíssimo que vale muito a pena ser presenciado. A dança nativa [criolla], purissimamente criolla, prolifera como tudo neste país 'hidroxigenado', e os que até pouco tempo viram em qualquer parte se dançar com "corte e quebrada", não têm ideia do que é essa dança moderna. (FERRARI, 2011, p. 146, tradução nossa).

Nesse relato jornalístico a palavra tango sequer é mencionada, possibilitando levantar hipóteses diversas sobre sua origem. Como na música, a influência negra será buscada no candombe e um passado criollo [nativo] será enfatizado por aqueles que, como Jorge Luís Borges, procuram atribuir ao tango um caráter nacionalista, afastando-se da contribuição dos imigrantes, principalmente italianos, no processo de formatação do tango; como se a própria noção de criollo não carregasse o peso do elemento ibérico com certo grau de mestiçagem nos nativos da América. Elemento ibérico que está presente nos gestos exacerbados e dramáticos do flamenco e do toureiro. A coreografia do tango também será interpretada como um duelo entre cuchilleros $^{1}$, que se movem em um ritmo sincronizado de pernas e braços sob o signo da destreza e da coragem, onde a propalada sensualidade do tango manifestar-se-ia entre iguais numa estética que conjugaria virilidade, honra, glória e paixão.

Que a coreografia do tango traduza os gestos marcantes de uma imaginada vida cotidiana é um aspecto que caracteriza a dança que, diversamente da música instrumental, não cessa na busca por signos fora de seu próprio sistema para atribuir um excesso de sentido aos seus movimentos que parecem demandar um significado.

Sabemos, antes de tudo, que todos os passos têm algum antecedente na vida cotidiana. A "corrida del bolsero", por exemplo, nasce de um movimento característico que fazem os trabalhadores do porto antes de

\footnotetext{
1 Termo lunfardo (dialeto portenho) que significa briguento, ou mais especificamente um tipo de pessoa hábil no manejo de armas brancas
} 
que exista o porto. [...] 0 mesmo ocorre com o chamado "passo bicicleta": o varão move o pé da dama como se fosse um pedal [...]. Também o trem, signo precoce da modernização, tem sua versão coreográfica no "passo do trenzinho", uma corrida do homem e da mulher em linha reta e de lado, com passos curtos e velozes. (PUJOL, 2011, p. 27, tradução nossa).

Toda atividade do homem está ligada a modelos de classificação do espaço e todos os tipos de divisão de espaço formam construções homomórficas, formula Lotman (1998). À vista disso, por meio de um mecanismo de duplicação, os gestos da vida cotidiana são copiados, ou melhor, traduzidos desse "fora para dentro" do espaço da dança no qual adquirem uma função. Apesar das analogias que se podem extrair entre as inúmeras figuras que compõem o repertório coreográfico do tango e as representações a que conduzem, a origem ou sequer o significado dos famosos 'cortes' e 'quebradas' não são facilmente decodificáveis no contexto da virada do século XIX ao XX em que vários estilos de dança eram praticados.

Dadas as semelhanças estruturais na música e na dança, o mais certo que se pode afirmar sobre o tango é que deva ter uma linhagem direta da criolla milonga suavizada pela valsa, além de ter herdado a dramaticidade do flamenco. Pode-se inferir com alguma margem de segurança que o ritmo, como elemento comum aos sistemas da música e da dança, é o dispositivo que permite que os códigos da música sejam traduzidos para a dança na produção de uma linguagem própria. A previsibilidade provém da ideia de que a variação sucessiva de notas e acordes musicais poderia ser replicada no sistema da dança por meio de movimentos corporais que copiariam essa métrica, traduzindo os códigos da linguagem musical para uma linguagem corporal. No entanto, essa correspondência, que no sistema linguístico ocorreria no nível semântico, torna-se ainda mais complexa no processo tradutório do sistema-música ao sistema-dança. Os eventuais significados que poderiam ser deduzidos da linguagem musical não se acomodariam no nível da sinonímia, mas da homonímia em que a polissemia deve ser acentuada pela diversidade de timbres, altura e intensidade que os sons apresentam ao longo de uma sintaxe musical, sem a qual o ritmo não seria perceptível.

A suposição é que uma nota musical seja desprovida de significado, mas, por outro lado, uma frase musical ritmada, ainda que tampouco nada signifique, poderá adquirir sentido na medida em que a polissemia musical apresente um conjunto de possibilidades semânticas que garantam uma margem de "traduzibilidade" a partir da qual se justifique o estabelecimento de um padrão. Consequentemente, uma sequência rítmica como a do tango 
poderia comportar algumas, mas jamais todas as variações possíveis na forma de dançar na medida em que estaria limitada pela especificidade de sua estrutura métrica; pela sua ordenação rítmica; pela construção melódica; além de outros elementos como a harmonia e o uso de contrapontos e texturas. Essa prosódia musical permitiria a tradução da linguagem musical para a corporal assumindo funções mais ou menos estáveis, ainda que insuficientes para consolidar um padrão na medida em que dependa de variáveis que não se encontram essencialmente no domínio desses sistemas, mas em regras que lhe são externas como a moral. No caso do tango, as premissas mais gerais que definem as regras de sua linguagem são de dois corpos abraçados, em que um assume a função de condutor e o outro de conduzido, não obstante um paradoxal uso de improvisação seja condição desse jogo. Há, portanto, uma matriz que é a dos corpos abraçados e do improviso com os pés, mas a dinâmica exige o entendimento e a comunicação da função que cada um dos pares assume na dança, de modo que o aprendizado dos códigos, como aquele que garante o conhecimento da sequência de passos e das principais figuras, deva ser ultrapassado pela capacidade de improvisar continuamente.

Mais que entender o processo de codificação e decodificação é preciso estar atento às constantes recodificações que cada par realiza a cada gesto, o que exige uma fina comunicação com o outro para que surja um terceiro neste diálogo: o tango dançado. Acerca desse terceiro no diálogo do tango, o coreógrafo e bailarino Rodolfo Dinzel, discorre:

É uma dança de dissociação. 0 que se passa abaixo não se passa acima. 0 aparato expressivo: as pessoas que dançam não gesticulam, as expressões são proporcionadas com as pernas. Acima, há um aparato dramático. Eu falo de um terceiro volume. São três os que dançam e não dois. São três volumes os que jogam nos eixos de equilíbrio e nas translações de peso do corpo. A mulher, o homem e um terceiro volume. Cada um sente como quiser dependendo com quem baile e segundo as circunstâncias. É a outra mulher do homem, é sua mãe, é outro homem. 0 homem enfrenta esse terceiro volume e a mulher o comparte. Depende da relação interior que se dê. (DINZEL entrevistado por AZZI, 1991, p. 33, tradução nossa).

Por um lado, é descrita uma relação dialógica entre os pares em que se deve buscar o eixo gravitacional de equilíbrio a partir deles. Por outro lado, observa-se um eixo assimétrico em que as funções expressivas das pernas que se movimentam devem estar em sintonia com um aparato dramático que organiza a afetividade simulada no abraço. A complexidade reside no cruzamento e articulação desses eixos espaciais que conduzem os movimentos verticais das pernas em assimetria com o tronco, com o horizontal da condução dos corpos pela pista, em que, além do domínio técnico implícito, exige-se uma comunicação 
afetiva que precisa ser controlada e dirigida à execução da dança segundo uma escuta atenta da música que resulta numa dinâmica estrutural do casal.

A assimetria estrutural está presente no eixo corporal de cada par que, a despeito dessa tensão, deve procurar um ponto de equilíbrio no movimento conjunto com o outro. 0 corpo divide-se em tronco e pernas que protagonizam funções tão distintas como aquelas realizadas na dinâmica condutor-conduzido. A regra de linguagem de dançar abraçado com uma coreografia improvisada, protagonizada principalmente pelos pés, é extremamente complexa, pois exige dos pares não apenas o conhecimento dos códigos, mas a astúcia de recodificá-los a partir de uma interação contínua que faz do tango um jogo por excelência: um processo cognitivo e, ao mesmo tempo, lúdico.

Como resultado do abraço no genuíno tango argentino, a postura dos corpos produz um $\mathrm{V}$ ao contrário (com maior ou menor ângulo), diversamente das caricaturas do tango dos filmes de Hollywood ou dos salões de baile. Essa posição dos corpos em $\mathrm{V}$ invertido favorece a dança, porque o abraço na altura do peito, intenso e flexível, facilita a melhor comunicação dos corpos. Os pés se separam para não dificultar a realização das figuras. (FERRARI, 2011, p. 33, tradução nossa).

Em uma geografia corporal, o elemento crítico está nas cadeiras que fazem o elo entre certa inflexibilidade do abraço e a liberdade criativa das pernas. Essa conexão não seria necessária se os pares dançassem separadamente de modo que cada um desenvolvesse uma coreografia própria, ou mesmo similar, no entanto, essa assimetria corporal de cada indivíduo deve se conjugar com as distintas figuras que realizam cada par do casal, tornando assaz complexa a dinâmica do tango. Do ponto de vista do corpo, como em qualquer dança de pares conjugados, exercita-se uma apreensão do espaço na relação com o outro e de comunicação com o outro, em que a linguagem emerge como um terceiro. Efetivamente, não se consegue dançar quando não se conhece o outro, quando não se sabe como conduzir ou ser conduzido pelo outro. E para tanto, não basta conhecer os códigos da dança e possuir um domínio técnico, porque, embora sejam necessários, são insuficientes para conseguir dançar abraçado. Por mais que se observe o outro à distância, somente quando os dois corpos colocam-se em movimento contínuo é que vão se conhecendo, adaptando-se e modificandose, tornando única a experiência de dançar. E por mais que se pretenda estabelecer uma conotação sexual ao tango, a relação ocorre efetivamente muito mais em uma dobra que conjuga o plano imanente do contato físico com o transcendente de um terceiro que se projeta para além do momento em que os dois dançam. A promiscuidade do tango está antes nessa terceira pessoa que se projeta na relação entre dois. Como decorrência, troca-se de 
par com frequência, pois a experiência que está em jogo não é a da sedução do outro pela atração sexual dos corpos, mas da atração sensual dos corpos em movimento. Pode-se, portanto, falar em promiscuidade se o termo significar essencialmente diversidade, assim como são promíscuos os desejos do paladar que procura variar a experiência sensorial dos sabores na degustação. Deste modo, compartilha-se da experiência de dançar o tango entre distintas faixas etárias e tipos físicos, ainda que se possa sublimar a presença do parceiro com a imagem de qualquer outro personagem ausente que se queira. Por outro lado, podese eleger um parceiro fixo, ou ao menos preferencial, para dançar por toda vida, sem que se opere qualquer tentativa explícita de sedução que ultrapasse o espaço da pista da dança. Ou seja, pessoas casadas ou comprometidas não raramente podem desfrutar de um 'outro' que é seu parceiro exclusivo no encontro dos corpos na dança. 0 jogo da comunicação no tango é antes um jogo de linguagem do que sedução explícita, cuja vontade de vencer é expressa na tentativa de compor sintaxes e produzir uma estilística em que se busque uma excelência dentro de um âmbito próprio.

Essa ligação visceral com o outro provém possivelmente da forte conotação sexual que o tango adquiriu em sua suposta origem prostibular. 0 lendário milonguero Carlitos Estevez, conhecido como Petróleo, conta que:

A forma de dançar em dupla fui eu quem a transformou. Eu inventei as coisas essenciais do tango. [...] Desvinculei o sexo da dança. Eu comecei em 1927 ou 1928 a dançar. Inventou-se um movimento que se chama "sobrepasso", aí o tango se transformou. (ESTEVEZ entrevistado por AZZI, 1991, p. 40, tradução nossa).

No entanto, muito antes disso, o tango já tinha se desprendido de seu viés prostibular sobre o qual, aliás, restam inúmeras dúvidas sobre que contribuições efetivamente teriam trazido para a modelização de sua linguagem. Sabe-se apenas que os passos curtos e ligeiros da marcação rítmica mais ágil de 2x4 foram sendo substituídos por passos mais longos e mais lentos conforme o bandoneón era introduzido nas orquestras típicas que então se estruturavam. A marcação $2 \times 4$ é possivelmente uma herança que tanto a milonga quanto o tango herdaram da forma de cantar 'corto' e 'picado' dos payadores que necessitavam de um tempo para respirar e responder no estilo repentista e contrapontístico, mas também é uma depuração que tendia simplificar as linguagens musicais a compassos binários, como no caso da guajira flamenca, feita em marcação $6 \times 8$, mas executada em $2 \times 4$, pelo predomínio da memória auditiva e pela falta de conhecimento do pentagrama, ou mesmo no uso do compasso elementar e binário do 2x4 que também viria do candombe (CARRETERO, 1999). 
Com a estruturação das orquestras típicas em torno de um naipe de instrumentos de execução mais sofisticada que exige um maior conhecimento técnico por parte dos músicos, os compassos passam a ser marcados em $4 \mathrm{x} 4$, fazendo com que figuras como giros, arrastres e ganchos viessem a suplantar as antigas quebradas, alterando os códigos da dança. No entanto, será o sobrepasso que permitirá que uma série de mudanças ocorra. "A mulher dá um passo para trás, e outro em seguida... e faz um sobrepasso, uma cruzada de pé que o homem desligará passando sua perna direita pela direita dela. É o momento do desvio: o casal pode pivotear em diversas direções ou girar sobre o próprio eixo", assim, o sobrepasso permitirá que o tango se torne mais 'clássico', e que “[...] se espraie pela pista, busque outros horizontes, faça que todos os espaços resultem insuficientes". (PUJOL, 2011, p. 174-175, tradução nossa).

De fato, pouco se sabe de como era executado e dançado o tango $2 \times 4$, mas estas fórmulas de compasso não chegam a comprometer o ritmo do tango atual. Isso é devido ao fato de que o aspecto diferencial reside, sobretudo, no hiato produzido entre a escritura e sua interpretação, causando uma sonoridade até certo ponto imprecisa, a que se chama de mugre, ou seja, é um jeito aparentemente imperfeito de tocar que marca um traço distintivo do tango para que soe tango. Estes hiatos ou descontinuidades na rítmica do tango executado ao gosto rio-platense seriam traduzidos pelos pés, “[...] adiantando-se ou atrasando-se o tempo forte do compasso", efeito que também se constataria no uso das síncopes que, na dança, resultam em “[...] certa suspensão do movimento, que se vê retardado, freado, para logo pisar com firmeza no chão quando o acento da música assim o requer." (FERRARI, 2011, p. 119-120, tradução nossa).

\section{A simulação do drible e o espetáculo erótico da tourada}

Essas suspensões dos movimentos, verdadeiras "simulações de imobilidade", essas súbitas pausas, movimentos que apontam em uma direção para seguir outra que tanto lembram os dribles do chamado futebol-arte, exigem destreza e uma contínua capacidade de improvisação como a que se nota nas figuras que compõem o tango dançado. A associação com as fintas do que se chama de 'futebol-arte' é oportuna, denotando a convergência entre técnica e improviso na produção de um jogo que seduz na medida em que ultrapassa a previsibilidade das regras. Exige o virtuosismo do jogador em seu domínio da bola e do espaço, demarcado não somente pelos limites do campo como também pela proximidade do adversário mais imediato e pela distância com os demais jogadores que podem lhe roubar a 
bola ou impedir a evolução necessária para que a finta seja bem-sucedida. Esse domínio do espaço requer um preciso controle do tempo para que a jogada ocorra prevendo-se uma futura configuração espacial dos demais jogadores para que se possa, eventualmente, fazer um passe na sequência do drible ou, ainda, desprezando a posição de todos os demais, conquistar o espaço que se tem pela frente e chutar ao gol. 0 'artístico' no drible reside justamente na capacidade em lidar com a improvisação, com o explosivo do inesperado, superando o controle das possibilidades de jogadas contido nas estratégias das equipes, algo que evidentemente não pode ocorrer na lógica restrita do xadrez, apesar de suas inúmeras combinações. Nenhum peão é capaz de surpreender, driblando a torre ou a rainha devido à capacidade antecipatória da estratégia dos jogadores. Esse componente 'artístico' não está previsto nas regras de linguagem do xadrez, pois não contemplam essas sintaxes transgressoras que colorem certos textos de cultura. No xadrez há apenas o preto e o branco.

0 drible é simulação e contém o 'veneno da linguagem' que é deliberadamente mentir com o propósito de convencer o adversário de que os sinais que estão sendo emitidos são verdadeiros, quando, de fato, estão invertidos. 0 objetivo, contudo, não é apenas enganá-lo, mantendo-se na invisibilidade discreta de um silêncio impune, mas humilhá-lo na exposição do ridículo da derrota e vangloriar-se pelo reconhecimento do exercício de uma farsa bem realizada. É justamente na visibilidade desse virtuosismo e desse excesso de transgressão que se satisfaz o jogador e o público. É nisso que reside o espetáculo. Um espetáculo no qual a semelhança com a tourada parece inequívoco, inclusive pela expressão olé que reproduz a catarse dos espectadores diante das fintas do toureiro em sua dança mortal com o animal humilhado em seu desespero por chifrar o vermelho e do adversário falhando ao alcançar a bola. Ainda que presente em outros jogos com bola, a finta é mais eficaz e espetacular no futebol na justa medida da proximidade que se mantém com o adversário, que não se encontra separado por uma linha, como no vôlei, mas encontra-se corpo a corpo como na dança. Além disso, movendo-se sobre o plano de um solo, a bola permite exibir todas suas instáveis potencialidades enquanto esfera e o jogador toda sua destreza em dominar esse escorregadio objeto. Da mesma maneira que na dança, a habilidade está, sobretudo, nos pés, embora exija um equivalente controle das cadeiras para gingar e do torso e braços para se equilibrar.

Sem a sinuosa bola a se interpor com o adversário, mas com a tensa e ostensiva presença de belicosos chifres em sua proximidade, o toureiro realiza uma provocativa, 
sensual e mortal dança com seu adversário em que novamente sua destreza na relação com o espaço é dirigida aos pés e ao controle das cadeiras nos giros do corpo. 0 toureiro provoca e seduz o touro num jogo de atração e morte, convidando-o para um tento que é o simulacro de uma dança silenciosa e em que sua posição é central, pois é a partir da qual o touro gira. Seus passos são curtos e econômicos, o suficiente para manter uma distância para que o touro passe enquanto ele gira, inclinando-se sobre seu próprio eixo na direção da mão que segura a capa [muleta], ao mesmo tempo em que a outra se apoia na sua cintura quando não está segurando a lança [rejoneador]. 0 jogo consiste em chamar o touro para uma proximidade que lhe será recusada até que termine lhe sendo mortal, cabendo ao toureiro desempenhar esse papel de sedução que se transfere para a dança, desde que se mantenham as devidas distâncias de contexto.

Essa transição de contexto das touradas à dança mostra-se com maior evidência no pasodoble que, juntamente com o flamenco, evidenciam os traços marcadamente ibéricos do tango principalmente naquilo que tange o gestual sensual e excessivamente dramático. Enquanto dançam abraçados, o casal realiza alguns giros com o corpo que lembram alguns passos do tango. No entanto, é sobretudo nos giros do corpo e nos trejeitos com os braços e as mãos do flamenco que as figuras ganham um excedente de sentido pelo seu exagero que beira o maneirismo. 0 virtuosismo dos dançarinos é expresso em gestos ágeis, fortes e marcantes, que se repetem em cada um dos pares, mostrando certa simetria e diálogos nos movimentos tanto dos pés, como dos braços e mãos, por vezes soltos, por vezes conjugados em corridas e giros. Movimentos que ganham uma expressão ainda mais incisiva pelo ritmo marcado das palmas e do acompanhamento das guitarras que se aprofunda com o taconeado. Todavia, a tradução dessas características no tango atenuou a exacerbação desses movimentos, deslocando-os em parte para os pés e silenciando-os no encontro do abraço, afeiçoando um sentimento mais controlado e, portanto, mais carregado de tensão, além de suavizado pela influência direta da milonga, mais alegre e saltitante, e, ao mesmo tempo, mais envolvente como a valsa com sua base orquestral. As eventuais simetrias também foram desfeitas, e a imposição de um regime de simultaneidade entre a proximidade do abraço e a improvisação constante dificultou sobremaneira a coordenação dos passos. Agora, os dribles e as fintas não visam derrotar o adversário, mas o mantém sob uma permanente tensão e dependem de sua igual destreza - e não de seu fracasso como no futebol e nas touradas - para que siga o baile. 
A 'improvisação controlada' do tango remete a imagens surpreendentes quando dançado a um ritmo artificialmente pausado, à velocidade de uma câmera lenta em que a coreografia rebuscada presente nas figuras pode ser mais bem observada. Esse efeito ainda pode ser acentuado se, eventualmente, houver um distanciamento maior entre os pares. Sob essa perspectiva, os gestos fortes, mas comedidos, guardam uma estranha semelhança tanto com as artes marciais orientais como com as representações cênicas de duelo entre cuchilleros, de compadritos ${ }^{2}$ ligeiros com sua faca em punho, em que os adversários medemse um ao outro antes de acercarem-se para um embate mais direto. Atendo-se a uma leitura dos movimentos quadro a quadro, em que os passos antes ligeiros dos pés, assim como o de cada gesto dos braços e giros de corpo, possam ser percebidos em sua sequência, em uma ilusória contiguidade espacial que se torna contínua com a aceleração de sua velocidade, o tango refaz o itinerário de uma luta que ao mesmo tempo é viril e poética. Miram-se firmemente nos olhos, encaram-se enquanto desenham um círculo no chão, prestes a sacar o punhal no momento preciso para vingar a terra ou um parente perdido, ou ainda, sem ódio, para cumprir com o desígnio de uma morte por encomenda.

Essa mitologia que estetiza a tensão e a violência dos duelos, primeiro entre os homens do campo, e, depois, em um movimento para o centro, para os arrabaldes - ou mesmo para Palermo ${ }^{3}$ - traduz o sentimento de hombridade, coragem e altivez do gaúcho de Martín Fierro e, acima de tudo, dos compadritos de Jorge Luís Borges que peleiam nas esquinas de Buenos Aires. Essa narrativa que mistura virilidade e sensualidade na melhor tradição dos westerns com toda a ambiguidade possível desse universo exclusivamente masculino, viril e inocente de guerreiros épicos, é introduzida no tango, adicionando um estrato semiótico à memória que torna menos esquemática sua habitual leitura. Essa mitologia que mistura sangue e areia, bailarinos e assassinos e que revive os mortos pelo tango, refaz no abraço essa memória do cruel e do perdido, mas não se esquece de manter os pés livres para caminhar e dançar.

\footnotetext{
2 Figura arquetípica dentro da mitologia do tango que o coloca como agenciador de prostíbulos e hábil no manejo com a faca. 0 compadrito também seria uma versão menos nobre e mais malévola da figura do compadre, herdando traços do gaúcho que, chegando à cidade, abandona o cavalo e passa a habitar em suas margens [orillas], vivendo da malandragem e de forma arrogante e sarcástica.

${ }^{3}$ Atualmente um bairro sofisticado de Buenos Aires, Palermo - onde Borges viveu e a que se referiu constantemente em sua obra -, na época referida (no início do século XX), ainda manteria uma característica de periferia.
} 


\title{
3 A experiência estética
}

Há diversas formas de dançar tango, estas se movem desde a milonga ao tango canyengue, do estilo mais picado, com mais cortes e quebradas, ao tango mais liso, mais valseado. A rigor, não é a época que vai determinar o estilo, mas o modo que cada orquestra imprime ritmo ao tango, aumentando sua massa sonora com mais instrumentos, valendo-se do uso ostensivo do rubato ou possibilitando que o tempo se acelere ou freie, não raramente de modo abrupto. Essas alternâncias rítmicas, possibilitadas por uma música produzida com uma base orquestral que combina diversos instrumentos em tempos diversos, ao serem traduzidas para a dança vão produzir uma oscilação equivalente nos movimentos do corpo. O tango levará os corpos a estados frequentes de suspensão, de tensão e distensão, que lhe imprimem um marca muito própria: por vezes, enfrentam-se como em desafio, ensaiando 'dribles' e 'fintas', por vezes, soltam-se pelo 'campo', pela pista, como em uma valsa.

\begin{abstract}
Se dançamos tango, é essencial o instante em que o pé se alça, antes de pisar o solo. Há um impulso, o de dar o passo, que pode ficar suspenso enquanto se dança, pois esse pé tanto pode demorar-se em pisar como acelerar-se. [...] É um mínimo instante, mas é máxima a agilidade e tensão que produz na dança. [...] A leveza do passo está na impulsão suspensa no espaço. A demora em por o pé no solo obriga ao dançarino a procurar um equilíbrio nesse único pé que não apenas sustenta todo o corpo, mas que o faz dançando. [...] A dançarina recebe essa impulsão do companheiro para se lançar na dança e tomar o rumo que lhe é sugerido, atingindo seu voo próprio. Esse passo que se dá será sempre depois dele, mas também será antes dele, pois o dançarino deve escutá-la, sentir seu jeito e então sugerir um novo passo. (FERRARI, 2011, p. 27-28, tradução nossa).
\end{abstract}

Esta tensão permanente entre os pares, em que os movimentos sugeridos por um exigem a atenta escuta do outro para que se possa corresponder uma sequência coordenada de passos, encontra-se longe de uma mera relação de codificação e decodificação de sinais diante da imprevisibilidade dos gestos improvisados que não comporta uma dedução do significado de cada movimento. O sincronismo entre os pares requer mais que o conhecimento prévio da estrutura gramatical da linguagem do tango, pois implica produzir uma sintaxe original a partir de dois sujeitos que também se encontram reciprocamente na condição de objeto. Não se trata, portanto, de apenas conhecer cada figura, de como fazer um oito, os giros, a corrida, a boleada, o molinete, a sentada ou a volcada. Todas essas figuras exigem uma coordenação motora e espacial que se explica pelas leis da física, mas mesmo sua perfeita realização técnica não garante que o tango seja expresso se não se considerar que o meio pelo qual se propaga essa energia - o corpo - seja sensível e, portanto, passível de uma vivência estética. 
Ao menos no caso do tango, dançar não significa apenas 'seguir o ritmo', mas também improvisar para além da tradução literal (decodificação) dos compassos. Tampouco improvisar significa criar coreografias ou gestos gratuitos que conduziriam qualquer dança a uma mera expressão do sentimento de escuta musical transposto ao movimento do corpo. A improvisação no tango é um lance de risco que pode comprometer todo o jogo, pois mobiliza um recurso estilístico que não se encontra previamente codificado, tendo que ser controlado e calculado para não comprometer o desempenho do parceiro. Por outro lado, a sistematização absoluta dos códigos, que levaria a formação de um padrão, conduz a uma dança estilizada, estandardizada, como a que se observa nos espetáculos de tango dedicados aos turistas em que os bailarinos profissionais mantêm-se dentro de uma disciplina severa na obediência aos códigos. Embora espetacular pelos gestos acrobáticos e a perfeição dos movimentos, a situação ideal decorre do equilíbrio entre a codificação dada pela técnica e a espontaneidade do improviso, que sempre se admite como um jogo entre dois; nunca liberto, portanto, do compromisso dessa regra. Petróleo (entrevistado por AZZI, 1991, p. 42, tradução nossa) reitera que "O tango não tem uma coreografia definida. Não há uma escola de tango. 0 tango não tem um padrão. Cada um cria a sua própria maneira", e complementa, dizendo que "O tango é uma dança que se inventa. Copes dança de uma maneira, Virulazo dançava de outra, Antonio Todaro dança de outra, todos são diferentes, nenhum é igual”.

\section{A ambivalência dos gêneros}

A despeito dessa liberdade criativa, o tango, como qualquer outra dança, apresenta algumas regras que cumprem determinadas funções no sistema e que carregam um conjunto de representações de seu contexto. Nesse sentido, o tango estrutura-se em códigos bem definidos quanto às funções que desempenham os gêneros masculino e feminino, reproduzindo as representações de uma cultura fundada nessa dicotomia. Na verdade, essa dicotomia é aprofundada não apenas por se dançar abraçado como também por arregimentar uma série de representações adicionais sugeridas pela exacerbação da sensualidade de suas figuras. Parte-se da suposição de que "Todos os bailes de casal estão destinados a exaltar a masculinidade do homem e a feminilidade da mulher [...]". (COOPER, 1997, p. 76, tradução nossa). No entanto, a operacionalidade do jogo não depende dessa regra moral, mas do cumprimento das funções elementares das danças de pares que antes exigem apenas as figuras do condutor e do conduzido. 0 coreógrafo e bailarino Juan Carlos Copes (entrevistado por AZZI, 1991, p. 23, tradução nossa) afirma que "O baile de tango é a 
busca do homem e da mulher. É a busca do abraço. É a forma de estar juntos e de que o homem se sinta homem e a mulher, mulher, sem machismo. À mulher, lhe agrada ser levada e ao homem levar". Copes estabelece, portanto, uma correlação necessária e natural entre as funções dos códigos da dança com os códigos ou padrões culturais. Por vezes, esse padrão teria sido inclusive interpretado como uma função sexual em que a dança seria apenas um meio e não um fim em si mesmo.

Há uma memória constituinte da evolução do tango legitimada em larga medida pela visão idealizada de Jorge Luís Borges sobre um passado prostibular do tango e pela contumácia em situar o compadrito como uma figura que sintetizava a coragem do gaúcho com a sensualidade um tanto perversa contida no seu modo de lutar que se assemelhava a uma dança, ao tango. A despeito dessa sensualidade, pode-se encontrar com alguma facilidade certa misoginia na representação do compadrito e na visão machista que entende que a mulher não pode fazer senão aquilo o que homem lhe determina. A mitologia do compadrito reza que ele é aquele que passa agenciar os prostíbulos ${ }^{4}$ e os tangos negros ${ }^{5}$ pela destreza no trato com faca, impondo assim sua presença em bairros centrais de Buenos Aires, como San Telmo e Montserrat. Aos poucos, esses compadritos também vão aprendendo a dançar, copiando alguns passos e figuras mais arrojadas dos negros:

\begin{abstract}
Inicialmente, o negro podia, apesar de sua inferioridade numérica, zombar dos brancos criollos ou imigrantes pela inexperiência que demonstravam quando se iniciaram no baile, pelos erros que cometiam. Essa chacota [burla] consistia na correta execução da coreografia, mas exagerando os passos para demonstrar que, apesar das liberdades que tomavam, não saíam do ritmo nem quebravam a cadência. Também consistia na mudança na coreografia, mas mantendo-se sempre dentro do ritmo musical. (CARRETERO, 1999, p. 27-28, tradução nossa).
\end{abstract}

Mais tarde, serão os criollos que passarão a imitar a coreografia dos negros, convertendo-se em hábeis bailarinos, dominando a cadência e introduzindo novas variações coreográficas ao ponto de rivalizarem com seus antecessores.

Nesse momento, imperou uma aparente anarquia ao enfrentarem-se dois mundos musicais e duas coreografias. As diferenças foram se decantando e atenuando, dando lugar a uma terceira que era comum aos negros e brancos, ainda que não definitiva, mas transitória. (CARRETERO, 1999, p. 64, tradução nossa).

\footnotetext{
${ }^{4}$ Pode-se dizer genericamente prostíbulo para se referir a uma diversidade de termos como lupanares, garitos, alojamientos ou cuartos de las chinas, embora, a rigor, impliquem em coisas diferentes.

${ }^{5}$ Quilombos ou lugares de encontro de negros e mestiços para se ouvir música.
} 
A reconstituição pode não ser fidedigna, contudo, demonstra o processo de comunicação de códigos da dança como tradução semiótica na produção de um texto de cultura que passa de um meio a outro: não apenas do negro ao criollo, do criollo a um terceiro, mas do sistema da dança ao da literatura que faz do compadrito um personagem central na semiótica do tango. Em um processo inverso, essa combinação de habilidades na coreografia, na faca e no sexo, fará do compadrito um signo do tango que se refletirá nos códigos cifrados da dança. Em larga medida, o compadrito será traduzido no sistema da dança como signo da masculinidade, assumido pela função de condutor. No entanto, a habilidade coreográfica pode ser também percebida como um componente estéril fora do contexto da dança, possibilitando inferir uma ambiguidade nessa caracterização aparente homogênea da masculinidade. 0 argumento que os homens pudessem dançar juntos prática comum no tango - com destreza sem comprometer sua masculinidade não seria sequer validado em uma época anterior aos anos de 1920 - quando o personagem do compadrito imperava no tango - e muito menos em locais como Buenos Aires que, a despeito de seu relativo cosmopolitismo, não era nenhuma Paris, tornando instigante essa equação que assenta masculinidade e desenvoltura coreográfica.

Evidentemente, os deslizamentos que se processam nas interpretações das culturas são procedimentos de risco: por um lado, o distanciamento permite uma confrontação com paradigmas estrangeiros a esses contextos, reacomodando e hierarquizando os estratos semióticos a partir de novos arranjos de sentido, ou seja, produzindo novas semioses; por outro lado, produzem proposições duvidosas se não denotam o conhecimento dos contextos que analisam. Portanto, é perfeitamente possível admitir que a destreza para dançar fosse efetivamente um signo de masculinidade no contexto do tango desde a época dos compadritos até o seu auge nos anos de 1940 ou mesmo depois. No entanto, é sempre possível sugerir na mesma medida uma margem de ambiguidade como a que é, por exemplo, denunciada no filme ¡Buenas noches, Buenos Aires! (1964, tradução nossa), em uma cena que um dos protagonistas baila com desembaraço com la morocha ; aparece então o compadrito preterido que observa a distância o casal, ele então se aproxima e provoca o parceiro de la morocha6, dizendo "[...] não sei por que, mas me parece que para bailar esses

\footnotetext{
6 Morocha designa morena, mas não necessariamente no sentido da pele, mas na cor do cabelo. Basta lembrar que Gardel, apesar do cabelo negro, tinha tez alva e era chamado de El Morocho. Nesse sentido, morocho também significa mais do que mestiço, remetendo ao caráter nativo do criollo, como um homem do campo. La morocha também se refere a um tango de 1905, de Enrique Saborido, com letra de Ángel Villoldo em que se afirma a vocação graciosa e altiva da companheira do gaúcho: "Sou a morocha argentina, a que não se lamenta, e alegre passa a vida com seu cantar. Sou a gentil companheira do nobre gaúcho portenho, a que guarda o carinho para seu dono”. (ROMANO, 2000, p. 24, tradução nossa).
} 
cortes está sobrando mulher e, talvez, faltando homem." 0 desfecho será trágico, mas a passagem marca bem a tensão que o papel masculino assume ao dançar com desenvoltura, mesmo quando na função protagonista de condutor, como não poderia deixar de sê-lo no caso.

Trata-se de um aspecto instigante sobre o papel masculino na dança que passa aparentemente despercebido na literatura sobre o tango, evitando resvalar no assunto. Ainda que os padrões culturais sejam extremamente variáveis conforme a época, o lugar e o tipo de dança - em que inúmeras vezes apenas os homens dançam juntos em diversos contextos culturais que a mulher encontra-se excluída -, a dança frequentemente reúne em torno de si os signos do primitivo, do popular e do feminino, de modo que a convergência do masculino à destreza na condução dos passos do tango não possa ser tomada como evidente e natural. Por mais que a visão romântica e sedutora entre um homem e uma mulher apareça como um signo estável na cultura do tango, não deixa de ser resultado de uma construção feita por representações que não se encontram implícitas nos códigos da dança, mas na apropriação de suas funções elementares do condutor e do conduzido. Semelhante equívoco ocorre com a transposição automática de um suposto passado prostibular do tango com a romanesca e poética imagem da dança como um lugar edênico de encontro. A esse respeito, Garramuño (2009) desfaz qualquer tentativa de reconciliação na sua interpretação do poema - Tango - de Ricardo Güiraldes, extraído de seu livro El cencerro de cristal, de 1915, no qual a lírica é substituída pela crueza de uma relação marcada pelo conflito entre os gêneros: "A relação entre esses gêneros diferentes - a relação sexual proposta pelo tango não se apresenta como uma articulação pacífica, mas como uma luta; não é algo que une, mas algo que desune e fere, chegando inclusive à morte". (GARRAMUÑO, 2009, p. 62).

Há dois agenciamentos de sentido que Garramuño (2009) observa no poema de Güiraldes: um que situa o tango no contexto vulgar com seu sentido de primitivo; outro que evidencia uma tensão no seu erotismo, contrapondo o homem à mulher, ao invés de uni-los. Por um lado, o primitivo sugere um ambiente propício ao conflito e ao caos, mas também, em outra chave de leitura, ao condicionamento, às rígidas representações que polarizam as figuras e as funções culturais do homem e da mulher. Por outro lado, a tensão erótica que o tango conduz não parece se solucionar de forma dialética, mas acentuar a improbabilidade desse encontro, aspecto que será salientado pelas letras das músicas, principalmente a partir da década de 1920, tratando poeticamente desse conflito em que o homem, 
curiosamente, não aparece como dominante, mas como dominado por uma paixão que não se poderá consumar fundamentalmente por motivos morais, dos quais a mulher será invariavelmente culpada. A princípio, as regras do tango parecem claras:

Na realidade, a coreografia do tango baseia-se em três premissas fundamentais: o abraço masculino, que abraça a mulher, é para dirigi-la, não para apertá-la, o corpo do homem atua como suporte do corpo da mulher para que se apoie nele e acompanhe o ritmo que se imprime; os pés são a liberdade criadora. (CARRETERO, 1999, p. 102, tradução nossa).

No entanto, essas premissas são questionadas em algumas frentes (GARRAMUÑO, 2009; ROSSI, 1958; SÁBATO, 2005). Vicente Rossi, (1958) afirma que “[...] não se dançava pelo contato momentâneo com a mulher, mas pela própria dança em si. A companheira só complementava a dupla; por isso, não se esperava dela mais que sua habilidade dançante", de modo que as alusões sensuais, para não mencionar as intenções sexuais, permanecem apenas no âmbito privado de cada subjetividade, mantendo a dança nos limites de suas regras estruturais e libertando-a de suas representações.

O que define cada lugar, homem ou mulher, é a técnica, o papel e o que deve fazer para realizar o baile. Não se define pela maior ou menor masculinidade ou feminilidade dos pares. Ainda que se costume confundir, este é um fenômeno imaginário adjacente à dança, o qual não o faz menos importante. Mas ninguém é mais ou menos masculino por dançar muito bem o tango, ainda que se costume atribuir virilidade aos bons dançarinos. (FERRARI, 2011, p. 102, tradução nossa).

Não se sabe de onde parte a imputação de virilidade aos bons dançarinos, quando se tem conhecimento que, paradoxalmente, a prática entre homens era comum, principalmente nos primórdios do tango. 0 que é inegável é que seja cultural o vínculo que se procura estabelecer entre masculinidade e destreza na dança, permitindo, portanto, a inversão de sentido em outros contextos em que essa habilidade é antes percebida como característica da 'graça feminina' da qual o homem deveria apenas ser observador. Isso resulta que a regra moral não seja senão uma variável dispensável ao cumprimento estrito das regras estruturais da dança que estão orientadas tão somente à execução de suas funções primárias de condutor e conduzido, que, somadas à improvisação de ambas as partes, fornecem as linhas gerais do tango. 0 próprio privilégio da condução é questionado pelo papel ativo que também desempenha o conduzido, no qual a passividade pode ser mais bem localizada na escuta e na interpretação atenta dos sinais emitidos pelo condutor do que em qualquer outro lugar. 0 papel ativo do condutor não é definido pela representação do gênero sexual, tampouco pela arbitrariedade que, em última instância, anularia a própria 
funcionalidade da dança, mas pelo maior domínio dos códigos e pela maior capacidade de antecipar os resultados das figuras improvisadas que se colocam em jogo. Implica, portanto, conhecer as funções do conduzido e, consequentemente, obter um maior grau de conhecimento do jogo na medida em que se trata de funções distintas, mas complementares.

Para além de quaisquer representações sociais, a função de condutor guardaria um segredo epistemológico fundamental: quem conduz pode ensinar o outro a dançar, mas o contrário não. Essa lógica interna da dança é o que explicaria, em parte, o fato de que a prática entre homens tenha sido um recurso comum na história do tango.

\begin{abstract}
Os jovens aprenderam a dançar sozinhos, com seus amigos ou nas academias [...] A instituição das "práticas" é muito comum nos 40. Ali os homens praticavam entre eles os passos que estreariam à noite no baile. As "práticas" ocorriam em salões alugados, academias ou simples casas de família onde se congregam os jovens milongueros. Ao anoitecer, os jovens tomavam um banho e arrumavam para o baile, destino final de tanta "prática". (PUJOL, 2011, p. 154-155, tradução nossa).
\end{abstract}

Como recorda o próprio Petróleo (entrevistado por AZZI, 1991, p. 44, tradução nossa): "Na academia sempre se dançava entre homens. No ano de quarenta havia academias, pagava-se trinta centavos, punham discos, um bandoneón. Assim, aprende-se entre homens. A mulher não participava".

\title{
5 Conclusões: sugerindo algumas hipóteses
}

Os depoimentos analisados reforçam a ideia de que os que melhor sabem dançar tango são justamente os que praticaram, ou praticam, com os homens, atenuando uma visão machista que os próprios tangueros arrogam à dança. É compreensível que a questão da sensualidade do tango esbarre no plano movediço da sexualidade equiparando o signo do gênero masculino numa ideia comum de heterossexualidade. Ainda mais compreensível é que essa confusão entre virilidade e heterossexualidade ocorra a partir do olhar de certas culturas - em que a brasileira é paradigmática nesse caso - em que as relações afetivas devem ser necessariamente atravessadas por uma função sexual. No entanto, a despeito do traço comum de latinidade, os argentinos, assim como os uruguaios e gaúchos, parecem mais afeitos à discrição do que a demonstrações públicas e explícitas de suas vontades sexuais, e, nesse sentido, a sensualidade do tango aparece antes como um efeito de simulação da complexidade do jogo de sedução do que uma representação estética do ato sexual. 
Trata-se de uma hipótese até certo ponto ousada, mas necessária para se repensar a própria linguagem do tango como dança em suas possibilidades de tradução semiótica que não se esgotam nas construções eróticas de forte apelo midiático que naturalizam as funções de condutor e conduzido a partir de gêneros sexuais, mas que recorrem à ambivalência dos gestos e dos sentidos. A possibilidade de entrever erotismo no futebol e na tourada, em que a mulher usualmente é excluída, reforça a ideia de uma necessária desnaturalização das representações dicotômicas dos gestos sexuais para se alcançar a dimensão estética imanente aos corpos em movimento. Trata-se antes, em quaisquer dos casos, de uma estrutura rítmica que coloca em interação o gestual do corpo em movimento com um conjunto de regras de linguagem mais ou menos rígidas que tendem a ser ultrapassadas pelos códigos das representações sociais que se refazem na perspectiva da ambivalência.

A ambivalência dos sinais, ou mesmo aquela contida na linguagem verbal, constitui-se assim numa chave para a compreensão da complexidade do processo comunicacional, rompendo com os esquemas binários que se satisfazem numa dialética do sim e do não. Neste caso, a lição do tango parece incitar o corpo à experiência única de uma comunicação de afetos, ao encontro pelo abraço e à imprevisibilidade do que se segue ao ritmo, e não seria senão na ambivalência de sentidos dos gestos em movimento que sua dança tem resistido ao estabelecimento de regras e padrões que reduzam seu potencial estético, permitindo a produção de novas traduções semióticas.

\section{Referências}

AZZI, María Susana. Antropología del tango: los protagonistas. 2. ed. Buenos Aires: Ediciones de Olavarría, 1991.

¡BUENAS NOCHES, BUENOS AIRES! Direção: Hugo del Carril. Argentina, 1964. Cena com "La morocha", precedida por solo de Troilo ao bandoneón. Disponível em:

$<$ http://www.youtube.com/watch?v=Nh1kQT9t99w>. Acesso em: 22/10/2013. Cena do twist. Disponível em: <http://www.youtube.com/watch?v=TguzXwGGJZY>. Acesso em: 21 jun. 2013.

CARRETERO, Andrés M. Tango, testigo social. 1. ed. Buenos Aires: Ediciones Continente, 1999. $160 \mathrm{p}$.

COOPER, Artemis. La tangomanía en Europa y Estados Unidos: 1913-1914. In: AZZI, et al. ¡Tango! El baile, el canto, la historia. 1. ed. Barcelona: Odín Ediciones, 1997. p. 67-113.

FERRARI, Lidia. Tango: arte y misterio de un baile. 1. ed. Buenos Aires: Corregidor, 2011. 
GARRAMUÑO, Florencia. Modernidades primitivas: tango, samba e nação. Tradução: Rômulo Monte Alto. Belo Horizonte: Editora UFMG, 2009.

PUJOL, Sergio. Historia del baile. De la milonga a la disco. 2. ed. Buenos Aires: Gourmet Musical Ediciones, 2011.

ROMANO, Eduardo (Coord.). Las letras del tango. Antología cronológica 1900-1980. 3. ed. Rosario: Editorial Fundación Ross, 2000.

ROSSI, Vicente. Cosas de negros. Buenos Aires: Librería Hachete, 1958.

SÁBATO, Ernesto. Tango: discusión y clave. 3. ed. Buenos Aires: Editorial Losada, 2005.

\begin{abstract}
Despite its complex coding system, the language of tango as a dance can only be understood through the constant improvisations that the couples perform, requiring a fine-tune in their movement intentions. However, the tango language exceeds those circumstances, becoming a communication of affect that reveals itself inside a unique experience that cannot be reproduced. Even if it is wanted to make tango as a representation of sensuality between men and women, it is proposed here a critical view of this gender identity, showing that its aesthetic expression transcends the social determination, raising a set of ambivalent representations that are not subjected to unique interpretations. In this article, although tango is conceived as a semiotic space itself, it is also possible to seek the understanding of their body language as a complex cultural system open to constant reinterpretations through some associations with other forms of language and social representations.
\end{abstract}

\title{
Keywords
}

Semiotic space. Body language. Gender identity. Ambivalence. Cultural system. Tango.

Recebido em 22/09/2014

Aceito em 27/11/2014 